(Unproofed version of article published as L. McDonagh (2019) Losing Ireland, losing the Empire: Dominion status and the Irish Constitutions of 1922 and 1937 International Journal of Constitutional Law, 17 (4). pp. 1192-1212)

\title{
Losing Ireland, Losing the Empire: Dominion Status and the Irish Constitutions of 1922 and 1937
}

\section{Introduction}

Word count: 9177

Word count (without footnotes): 6,923

"If we lose Ireland, we have lost the Empire."1

The above quote reflects the very real fear in the late 19th and early 20th century within parts of the British establishment that resolving the 'Irish Question' by creating a path - via Home Rule, or otherwise - to independence for Ireland would inevitably lead to calls for independence elsewhere within the British Empire. So it did prove: whether it was truly determinative or not, acceptance of Irish sovereignty - first as a Dominion, then as a republic - did indeed foreshadow the break-up of the Empire, which by the mid-20th century could no longer hold on to many of its territories, weakened by the enormous strain of Britain's participation in two world wars, and run ragged by the diverse anti-colonial rebellions that had engulfed Britain's Asian, African and Caribbean colonies. ${ }^{2}$

In this article I argue that Ireland ${ }^{3}$ represents a constitutional bridge between the old Dominions of Canada (and Newfoundland), Australia, New Zealand and South Africa - the 'settler

\footnotetext{
${ }^{1}$ Chief of the Imperial General Staff, Field-Marshal Sir Henry Wilson to Malcolm Arnold Robertson, 30 March 1921, in K. JEFFREY (ed.), THE MILITARY CORRESPONDENCE OF FIELD-MARSHAL SIR HENRY WILSON, 1918-1922 250 (1985).

${ }^{2}$ See generally J. BROWN \& WM. ROGER LOUIS, THE OXFORD HISTORY OF THE BRITISH EMPIRE: VOLUME IV: THE TWENTIETH CENTURY (2001).

${ }^{3}$ In this paper, unless otherwise stated, references to 'Ireland' refer to the state of Éire/Ireland as proclaimed in the 1937 Constitution of Ireland (the territory previously known as the Irish Free State from 1922-1937),
} 
colonies' that were recognised as having Dominion status pre-WWI - and the new Dominions of the post-WWII period: India, Pakistan, and Ceylon (Sri Lanka). ${ }^{4}$ Ireland's status as a bridge between old and new Dominions can be observed from the fact that Canada, a key old Dominion, provided the model for Ireland's constitutional status, something explicitly recognised in the Anglo-Irish Treaty of $1921 .^{5}$ Furthermore, Ireland enjoyed considerable political support from the old Dominions (especially South Africa and Canada) at Imperial Conferences during the 1920s, helping to ensure recognition of Ireland's sovereignty internationally. ${ }^{6}$ Contemporaneously, political, legal and cultural links emerged between Irish nationalists and other anti-imperialists in prospective new Dominions - especially in India. ${ }^{7}$

This article describes how the drafting of the Constitution of the Irish Free State (Saorstát Éireann) 1922 (hereafter, the 1922 Constitution) occurred, and how tensions over Ireland's Dominion status eventually led to the enactment of a new constitution in 1937. Notably, in 1922 the freedom to develop a new constitution was constrained. ${ }^{8}$ The British insisted upon the Dominion model, which required the presence of the Governor General as the King's representative in Ireland; the right of appeal to the Judicial Committee of the Privy Council (JCPC); the requirement of taking an oath to the Crown before taking a seat in the Irish Parliament, known as the Oireachtas, made up of the Dáil (lower house) and the Seanad (upper house); and, importantly, that no amendments could be made to the 1922 Constitution that would breach the Anglo-Irish Treaty 1921, which mandated these key restrictions. Moreover, the British only warily accepted the Irish delegation's democratic innovations, namely the use

encompassing 26 counties of the island of Island. The remaining 6 counties of Northern Ireland remain part of the United Kingdom.

4 P. Oliver, Dominion Status: History \& Framework ICON submission (2017) on file with author. See also H. Kumarasingham, The "Tropical Dominions": The Appeal of Dominion Status in the Decolonization of India, Pakistan and Ceylon, 23 TRANSACTIONS OF THE RHS 223, 223-245 (2013).

${ }^{5}$ Final text of the Articles of Agreement for a Treaty between Great Britain and Ireland (London, 6 December 1921), No. 214 DE 2/304/1 in DOCUMENTS ON IRISH FOREIGN POLICY VOLUME 1 1919-1922 (1998). http://www.difp.ie/docs/1921/Anglo-Irish-Treaty/214.htm

${ }^{6}$ R.M. DAWSON (ed.), THE DEVELOPMENT OF DOMINION STATUS 1900-1936 104-105 (2014). See generally D. Harkness , 'Mr De Valera's dominion: Irish relations with Britain and the commonwealth, 19321938,' 8 Journal of Commonwealth Political Studies (1970), 206-228, D. HARKNESS, THE RESTLESS DOMINION: THE IRISH FREE STATE AND THE BRITISH COMMONWEALTH OF NATIONS 1921-31 (1970), N. MANSERGH, THE IRISH FREE STATE: ITS GOVERNMENT AND POLITICS (1934), N. MANSERGH, SURVEY OF BRITISH COMMONWEALTH AFFAIRS: PROBLEMS OF WARTIME COOPERATION AND POST-WAR CHANGE 1939-1952 (1958) and D. Lowry, 'The captive dominion: imperial realities behind Irish diplomacy, 1922-49’ 36 Irish Historical Studies (2008), 202-226.

7 J. Cleary, Amongst Empires: A Short History of Ireland and Empire Studies in International Context, 42 ÉIRE-IRELAND 11, 31-32 (2007). See also B. Crosbie, Networks of Empire: Linkage and Reciprocity in Nineteenth-Century Irish and Indian History, 7 HISTORY COMPASS 993, 993-1007 (2009).

${ }^{8}$ DOCUMENTS ON IRISH FOREIGN POLICY VOLUME 1 1919-1922 216-370 (1998). 
of proportional representation (PR) in elections and, after a transitory period when amendments could be made via ordinary legislation, the use of popular referendums for approving constitutional amendments. ${ }^{9}$ Nonetheless, with the 1922 document Irish constitutionalists successfully merged elements of the Westminster model with liberal rights-based constitutional review. ${ }^{10}$ This innovation went beyond the rights protections in the Dominion constitutions of Canada, ${ }^{11}$ Australia, ${ }^{12}$ New Zealand ${ }^{13}$ and South Africa, ${ }^{14}$ influenced later constitutional developments in India, ${ }^{15}$ and would not come to the fore in British constitutionalism until the late 1990 s. ${ }^{16}$

The significance of the Irish experience from 1922-1937 is further illustrated when one considers that it involved the reconciliation of two key principles: Parliamentary sovereignty and constitutional autochthony. ${ }^{17}$ The need to reconcile these two principles becomes obvious when one asks an important question: what was the constitutive moment of the Irish Free State? The answer is not obvious. In 1922 the Imperial Parliament at Westminster passed legislation ${ }^{18}$ recognising the legitimacy of the Irish Free State and its constitution, later evaluated by the JCPC. ${ }^{19}$ Meanwhile, on the Irish side, acceptance of the 1922 Constitution came about after Ireland's Third Dáil, acting as a constituent assembly, enacted it into law, ${ }^{20}$ later confirmed as a constitutive act by the Irish Supreme Court. ${ }^{21}$ The Irish Free State, therefore, relied on both

\footnotetext{
${ }^{9}$ See generally T. Mohr, British Involvement in the Creation of the Constitution of the Irish Free State, 30 DUBLIN UNIVERSITY LAW JOURNAL 166-186 (2008).

10 The State (Ryan) v Lennon [1935] 1 I.R. 170.

11 The British North America Act, 1867.

12 The Commonwealth of Australia Constitution Act 1900.

${ }^{13}$ New Zealand Constitution Act 1852 (15 \& 16 Vict. c. 72).

14 South Africa Act 1909.

15 The Constitution of India (as on 9th November 2015) - http://lawmin.nic.in/olwing/coi/coi-english/coi4March2016.pdf

${ }_{16}$ Human Rights Act 1998.

17 P. OLIVER, Constitutions, Autochthonous in MAX PLANCK ENCYLOPEDIA OF COMPARATIVE CONSTITUTIONAL LAW (forthcoming, 2017) (copy on file with author). See also A.V. DICEY, AN INTRODUCTION TO THE STUDY OF THE LAW OF THE CONSTITUTION (1885), I. JENNINGS \& C.M. YOUNG, CONSTITUTIONAL LAWS OF THE BRITISH EMPIRE (1938), K. WHEARE, THE CONSTITUTIONAL STRUCTURE OF THE COMMONWEALTH (1960), K. Robinson, Constitutional Autochthony in Ghana, 1 JOURNAL OF COMMONWEALTH POLITICAL STUDIES 41 (1961) and G. MARSHALL, CONSTITUTIONAL CONVENTIONS - THE RULES AND FORMS OF POLITICAL ACCOUNTABILITY (1984).

18 Irish Free State (Agreement) Act 1922 and Irish Free State Constitution Act 1922.

19 Moore v The Attorney-General for the Irish Free State [1935] A.C. 484.

${ }^{20}$ Constitution of the Irish Free State (Saorstát Eireann) Act, 1922.

21 The State (Ryan) v Lennon [1935] 1 I.R. 170.
} 
external and internal constitutive acts. ${ }^{22}$ Analysing this disputed constitutive moment sheds light on Ireland's transition to a republic, which occurred first, through the dismantling - via law - of the 1922 Constitution, and second, through the enactment of a new constitution by plebiscite in 1937, before Ireland formally left the Commonwealth in 1949. ${ }^{23}$ As shown over the course of this article, from both the external (Imperial) and internal (Irish) constitutional perspectives, this process was rife with ambiguities.

Thus, while Ireland's Dominion status can be viewed as a legal mechanism for the exercise of internal sovereignty during the 1922-1937 period and a path to full independence post-1937, there is much more to say. Not only did Irish independence foreshadow Britain's loss of its Empire, from a constitutional perspective Ireland's experience as a bridge between the old and new Dominions influenced later constitutional developments in India, Pakistan and Ceylon. ${ }^{24}$ Finally, almost a century after the birth of the Irish Free State, two recent developments in the $\mathrm{UK}$ - the growing importance of referendums and the liberal rights-based adjudication that occurs under the Human Rights Act 1998 - mean the British Constitution itself has come to resemble its Irish descendant. ${ }^{25}$

\section{Establishing the political context of the negotiations over the Anglo-Irish Treaty 1921 and the 1922 Constitution}

During the early late $19^{\text {th }}$ and early $20^{\text {th }}$ centuries the Irish Question was a major issue in British politics, framed by the quest, led by John Redmond MP, for Irish Home Rule within the United Kingdom. ${ }^{26}$ Setting the scene for Ireland's later role as the bridge between the old and new Dominions, Irish Home Rule became an issue that closely united Irish politicians with their Indian counterparts - in 1892 Dadabhai Naoroji became the first Indian MP elected to the Westminster Parliament, representing Finsbury Central on a Liberal Home Rule ticket. ${ }^{27}$

\footnotetext{
22 The State (Ryan) v Lennon [1935] 1 I.R. 170. See also T. MOHR, British Imperial Statutes and Irish Sovereignty: Statutes Passed After the Creation of the Irish Free State, 32 JOURNAL OF LEGAL HISTORY 61, 61-85 (2011).

${ }^{23}$ D. MCMAHON, REPUBLICANS AND IMPERIALISTS: ANGLO-IRISH RELATIONS IN THE 1930s 186, (1984).

24 W. David McIntyre, A formula may have to be found': Ireland, India, and the headship of the Commonwealth, 91 THE ROUND TABLE 391, 391-413 (2002).

25 T. Poole, The Constitution and Foreign Affairs, 69 CURRENT LEGAL PROBLEMS 1, 9 (2016).

26 J. Knirck, The Dominion of Ireland: The Anglo-Irish Treaty in an Imperial Context' 42 ÉIRE-IRELAND 229, 244 (2007). See also A. O'Day, IRISH HOME RULE, 1867-1921 (1998).

${ }^{27}$ H.V. Brasted, Irish models and the Indian National Congress 1870-1922, 8 SOUTH ASIA 24 (1985).
} 
Simultaneously, strong cultural links between Ireland and India also began to emerge, particularly in the literary and theatrical fields, most notably between Rabindranath Tagore, W.B. Yeats and Patrick Pearse. ${ }^{28}$

The Irish and Indian nationalist causes provided twin headaches for the defenders of the British Imperial constitution. Notably, AV Dicey opposed both Irish Home Rule and democratic representation for Indians within the Empire, believing that: (i) to give in on either ground would be a clear repudiation of Empire; and (ii) the Irish and the Indians were insufficiently civilized to manage their own affairs. ${ }^{29}$ Nevertheless, Irish Home Rule made it onto the statute books in 1914 - however, its effect was suspended with the outbreak of WWI. ${ }^{30}$

It was in the midst of WWI - in 1916 - that the 'Easter Rising' occurred, with Patrick Pearse, Tom Clarke, James Connolly and others proclaiming the 'Irish Republic', and leading a shortlived rebellion against British rule, localised mainly in and around Dublin. ${ }^{31}$ Given its failure, in one sense the rebellion could be seen as a mere scuffle in the wider arena of anti-imperial conflicts; but in another it can be identified as a major destabilising moment for both the United Kingdom of Great Britain and Ireland, and the Empire as a whole. ${ }^{32}$ The event - or rather its aftermath, when the heavy-handed military justice (executions) handed out to the rebels turned public opinion decisively against the British authorities - radicalised a generation of Irish nationalists, and effectively brought an end to popular support for Irish Home Rule within the $\mathrm{UK} .^{33}$

\footnotetext{
${ }^{28}$ L.B. Williams, Overcoming the "Contagion of Mimicry": The Cosmopolitan Nationalism and Modernist History of Rabindranath Tagore and W. B. Yeats, 112 THE AMERICAN HISTORICAL REVIEW 69, 69-100 (2007) and E. Said, Yeats and Decolonization, in T. EAGLETON, F. JAMESON \& E. SAID (eds.), NATIONALISM, COLONIALISM AND LITERATURE 69, 69-96 (1990).

${ }^{29}$ D. Lino, Albert Venn Dicey and the Constitutional Theory of Empire, 36 OJLS 751, 753-66 (2016), A.V. Dicey, England and Ireland, 35 NATION 267 (1882) and A.V. Dicey, 'Imperial Rule in India - I' THE SPECTATOR 12 (1899).

${ }^{30}$ D. McMahon, Ireland and the Empire-Commonwealth, 1900-1948 in J. BROWN \& WM. ROGER LOUIS, THE OXFORD HISTORY OF THE BRITISH EMPIRE: VOLUME IV: THE TWENTIETH CENTURY 138, $146(2001)$.

${ }^{31}$ Ibid.

32 Ibid. For recent studies of the Easter Rising see R.F. FOSTER, VIVID FACES: THE REVOLUTIONARY GENERATION IN IRELAND 1890-1923 (2014) and R.S. GRAYSON \& F. McGARRY (eds.), REMEMBERING 1916: THE EASTER RISING, THE SOMME AND THE POLITICS OF MEMORY IN IRELAND (2016).

${ }^{33}$ D. Fitzpatrick, Irish consequences of the Great War, 39 IRISH HISTORICAL STUDIES 643, 643-646 (2015).
} 
In the post-WWI UK general election of December 1918, the pro-independence and anti-Home Rule party Sinn Féin won a large majority of Irish constituencies. Rather than taking their places at Westminster, in January 1919 these MPs instead set up an underground parliament in Dublin known as the First Dáil, issuing a 'Declaration of Independence' on 21 January 1919 that referred explicitly to the republican proclamation of $1916 .{ }^{34}$ Simultaneously, the First Dáil declared a 'Message to the Free Nations of the World' seeking support from 'every free nation' to support Ireland's new national status. ${ }^{35}$ Dáil representatives then attempted to gain recognition of their fledgling republic from the leaders of the Paris Peace Conference in 1919, where they hoped - to no avail, ultimately - for support from US President Woodrow Wilson. ${ }^{36}$

Back in Ireland the First Dáil quickly established a shadow administration for running the country, and nationalist militants from the Irish Republican Army (IRA) began a guerrilla warfare campaign against the British. ${ }^{37}$ During this period, commonly known as the 'War of Independence' (1919-1921), British authorities in Ireland found themselves ensnared in an asymmetrical armed conflict with the IRA, whose support amongst the local population increased with every British reprisal. ${ }^{38}$ Alarmed by the assassinations of policemen and other British figureheads (a campaign spearheaded by Michael Collins) - the British increasingly began to lose their grip on power, particularly in the areas outside Dublin, where 'Dáil loans' gave financial support to local authorities, and a set of shadow courts - the 'Dáil Courts' administered justice. ${ }^{39}$ Having finally understood that the heavy-handed suppression of militants and their supporters - including the use of the notorious 'Black and Tan' auxiliaries was backfiring, in 1921 the British realised they must begin negotiations over self-government with the key nationalists: Éamon De Valera, Arthur Griffith and Michael Collins. ${ }^{40}$

\footnotetext{
34 'Declaration of Independence' in Minutes and Proceedings of the First Dáil of the Republic of Ireland 19191921 (Dublin, 1994), No. 1. - http://www.difp.ie/docs/1919/Declaration-of-independence/1.htm 35 'Message to the Free Nations of the World,' Minutes and Proceedings of the First Dáil of the Republic of Ireland 1919-1921 (Dublin, 1994) - http://www.difp.ie/docs/1919/Message-to-the-Free-Nations-of-theWorld/2.htm

36 'Official Memorandum in support of Ireland's demand for recognition as a sovereign independent state. Presented to Georges Clemenceau and the members of the Paris Peace Conference by Sean T. O'Ceallaigh and George Gavan Duffy' (June 1919) No. 13, NAI DE ES Paris 1919 in DOCUMENTS ON IRISH FOREIGN POLICY VOLUME 1 1919-1922 20-25 (1998) - http://difp.ie/viewdoc.asp?DocID=13

37 B. Kissane, Electing not to fight: elections as a mechanism of deradicalisation after the Irish Civil War 1922 1938, 6 INTERNATIONAL JOURNAL OF CONFLICT AND VIOLENCE 41, 41-45 (2012).

${ }^{38}$ R. ENGLISH, ARMED STRUGGLE: A HISTORY OF THE IRA 15-23 (2003).

${ }^{39}$ See generally F.M. CARROLL, MONEY FOR IRELAND: FINANCE, DIPLOMACY, POLITICS AND THE FIRST DÁIL ËIREANN LOANS, 1919-1936 (2002).

40 R. ENGLISH, n 37, 40.
} 
The fact that Irish militant activities had forced the British to the negotiating table did not go unnoticed elsewhere in the Empire, most notably in India. Anti-imperialists within the Indian Congress believed the Irish precedent could provide 'a model for what might shortly be offered to India'. ${ }^{41}$ In 1922 Motihal Nehru and C.R. Das even formed a group - the Swarajya Party within Congress 'aiming for a swift transition' to Dominion status. ${ }^{42}$ Further to this, drawing a contemporary analogy between Collins and Gandhi, Von Tunzelmann describes the circumstances in 1922 that led the British to plan to arrest Gandhi and crack down on political protests, noting that had things worked out differently India may well have shortly followed Ireland's example by becoming a Dominion in the early 1920s:

"Gandhi would be offered a deal, just as Collins had been offered a deal. All he had to do was stand firm. It came as a surprise, then, that Gandhi did not stand firm."43

Rather than pursue an immediate settlement based on Dominion status, Gandhi backed away from his pursuit of self-government - alarmed by an incident of mob violence in Chauri Chaura in the United Provinces - and momentum was lost. ${ }^{44}$ It would be more than two decades before Dominion status again became a realisable goal for Indian nationalists.

Meanwhile, just prior to the beginning of the official discussions between the Irish nationalists and the British, the Imperial Parliament at Westminster passed the Government of Ireland Act 1920, which effectively partitioned Ireland north and south, paving the way for a settlement based on a determination that whatever happened to the remainder of the country, the six counties of what thereafter became known as Northern Ireland would remain within the United Kingdom. It is within this context that Ireland's Dominion status was negotiated and agreed in 1921.

The Negotiations over the Anglo-Irish Treaty 1921 and the Drafting Process of the Constitution of the Irish Free State 1922

\footnotetext{
${ }^{41}$ A. VON TUNZELMANN: THE SECRET HISTORY OF THE END OF AN EMPIRE 67 (2007).

42 Ibid., 77.

43 Ibid., 67.

44 Ibid.
} 
At the outset of the discussions with the British, the Irish argued for complete independence from Britain, not mere Dominion status:

"Ireland's full claim is for a Republic, unfettered by any obligations or restrictions whatsoever." 45

It soon became clear, however, that the British would offer nothing beyond the Dominion model. As a result, the year-long negotiations over the Anglo-Irish Treaty 1921 and the draft Constitution of the Irish Free State were torturous, with subjects such as the role of the Governor General, the oath of allegiance to the Crown for Irish parliamentarians, the right of appeal to the Judicial Committee of the Privy Council (as the final constitutional arbiter), recognition of the six Ulster counties within the newly constituted Northern Ireland, and a number of strategically important Irish ports that the British intended to retain control over particularly difficult to resolve. ${ }^{46}$

\section{The Treaty}

During the discussions, the British insisted the most relevant comparative constitutional model for Ireland's forthcoming Dominion status was that of Canada ${ }^{47}$ On this the British emphasised that Canada had effective independence over its internal matters. ${ }^{48}$ The Irish countered that 'the Crown in the Dominions was merely a symbol but in Ireland a reality' ${ }^{49}$ Eventually, the British relented on this point, and offered to put in any phrase in the Treaty that would reassure the Irish that 'the Crown in Ireland should be no more in practice than it is in Canada or any Dominion'. ${ }^{50}$ At the same time, the Irish negotiators - Michael Collins and Arthur Griffith chief among them - fought hard against the imposition of the oath of allegiance and the right of appeal to the Privy Council but were unable to find a way around either. ${ }^{51}$

\footnotetext{
45 'Memorandum by Erskine Childers' 23 November 1921 No. 201 NAI DE 2/304/1 in DOCUMENTS ON IRISH FOREIGN POLICY VOLUME 1 1919-1922 314 (1998) - http://www.difp.ie/docs/1921/Anglo-IrishTreaty/201.htm

${ }^{46}$ DOCUMENTS ON IRISH FOREIGN POLICY VOLUME 1 1919-1922 216-370 (1998).

47 Final text of the Articles of Agreement for a Treaty between Great Britain and Ireland, $\mathrm{n} 4$.

${ }^{48}$ North America Act 1867. See also decision of the JCPC in Edward v Attorney-General of Canada [1930] AC 124 at 136.

49 'Correspondence between Arthur Griffith and Eamon De Valera' 29 November 1921 No. 206, UCDA P150/194 - DOCUMENTS ON IRISH FOREIGN POLICY VOLUME 1 1919-1922 319 (1998).

${ }^{50}$ Ibid.

51 T. Mohr, n 8, 167-174.
} 
Finally, the British and Irish negotiators came to an agreement on a Treaty text, though it proved unpalatable to De Valera, who had remained in Ireland while discussions took place in London. De Valera rejected the document on several grounds, prominently the existence of the oath of allegiance and the continuing status of Northern Ireland within the UK. He instead proffered his own proposal for an independent Ireland having 'external association' with the Crown, but this was rejected by the British (though as discussed later on, it would have an afterlife in India). ${ }^{52}$ This led to a major split between a slim majority of Irish nationalists who sided with Collins and backed the Treaty, and a substantial minority who backed the anti-Treaty side headed by De Valera.

\section{The Constitution}

The drafting process of the 1922 Constitution was initially complicated by the Treaty negotiations and later by the input - for some, interference - of British politicians and lawyers. ${ }^{53}$ The British baulked at a number of the initial draft's proposals, including its most progressive innovations: the focus on legislative, rather than executive, power; the use of referendums to amend the text of the constitution; and the use of proportionate representation as the voting system for general elections.

A compromise was found: the 1922 document included provisions that emphasised the executive's power to dissolve parliament (a key point for the British); nevertheless, at the Irish insistence both the system of constitutional referendums and the use of PR in elections were retained. Yet, despite the requirement that constitutional amendments must be approved by a popular referendum, an exception was put into the text: Art 50 of the 1922 Constitution allowed the legislature to amend the constitution via ordinary legislation for a limited period - eight years - ostensibly in order to deal with constitutional 'fine-tuning' during the state's early years (though crucially this provision would come to be used much more widely). ${ }^{54}$

\footnotetext{
52 'Proposed Treaty of Association between Ireland and the British Commonwealth presented by Eamon De Valera to Dail Eireann' January 1922 No. 218 NAI DE 4/5/13 in DOCUMENTS ON IRISH FOREIGN POLICY VOLUME 1 1919-1922 367-370 (1998).

53 T. Mohr, n 8, 167-174.

54 The State (Ryan) v Lennon [1935] 1 I.R. 170.
} 
In terms of the 1922 Constitution's other legal innovations from the Westminster model, primary among them were the provisions in Articles 6-10 guaranteeing civil rights - to liberty, private property, freedom of religion and conscience, and freedom of speech; meanwhile Articles 65 and 66 of the 1922 Constitution vested the Irish High Court - and, on appeal, the Irish Supreme Court - with express powers of rights-based judicial review of legislation. As Hogan opines, the existence of these enumerated rights and the provision of constitutional judicial review represented 'a radical break with the previous British constitutional tradition, where the doctrine of the supremacy of parliament was fundamental'. ${ }^{55}$ Nonetheless, in practice - perhaps influenced by ongoing sporadic violence by nationalist republicans - during the Dominion period the Irish courts regularly deferred to the will of the executive and legislature over these matters, particularly with regard to habeas corpus in the context of suspected militants. ${ }^{56}$

\section{Twin Constitutive Moments? Acceptance of the 1922 Constitution in Dublin and London}

The Second Dáil accepted the Anglo-Irish Treaty 1921 on the 7th of January, 1922. Later that year the Imperial Parliament at Westminster accepted Ireland's new status, passing the Irish Free State Constitution Act 1922; while the equivalent Constitution of the Irish Free State (Saorstát Éireann) Act was passed by the Third Dáil, acting as a constituent assembly. ${ }^{57}$ The Irish Free state therefore came into existence via two parallel legal streams - Imperial and Irish.

As noted earlier, that mere Dominion status - not full independence - had been secured led to a fissure within the Irish nationalist movement between the pro-Treaty side that accepted the new Free State and its constitution (headed by Collins), and the anti-Treaty side (headed by De Valera). This exploded into a full blown civil war during 1922-23, leading to the assassination of Collins by the IRA and the emergence of two separate political parties: Cumann na

\footnotetext{
55 G. HOGAN, THE ORIGIN OF THE IRISH CONSTITUTION 1928-1941 3 (2012). See also Human Rights Act 1998, s. 3-4.

56 See, e.g., R. (Childers) v. Adjutant General, Provisional Forces [1923] 1 IR 5, and R. (Johnstone) v. O'Sullivan [1923] 1 IR 13, as noted by G. Hogan, N 54, 3 at fn 10. See also G. Hogan, Hugh Kennedy, the Childers Habeas Corpus Application and the Return to the Four Courts in C. COSTELLO (ed.), THE FOUR COURTS: 200 YEARS 177 (1996) and R. Keane, "The Will of the General": Martial Law in Ireland, 15351924, 25-27 IRISH JURIST 151 (1990-2).

57 T. Mohr, n 8.
} 
nGaedheal, led by William Cosgrave (precursor to today's Fine Gael party) and, later, Fianna Fáil, led by Eamon De Valera, which broke away from the abstentionist Sinn Féin in 1926.

Amid the civil war, the Free State's institutions began to take shape. In addition to the legislature and the system of courts, the 1922 Constitution envisaged the setting up of a governing executive known as the Executive Council of the Irish Free State. In 1922 William Cosgrave, whose party held the majority of seats in the Dáil, was elected the first President of the Executive Council. Importantly, however, whatever the will of the Irish executive and legislature, the Irish Free State's ability to legislate on constitutional matters was limited. As noted earlier, the restrictions on Irish sovereignty contained within the 1922 Constitution - and protected by the Treaty - included the presence of the Governor General as the King's representative in Ireland (retaining the power to 'reserve' Bills passed by the Oireachtas, and to sign them into law, or to refuse to do so); the requirement of Irish parliamentarians to take an oath of allegiance to the Crown; and the availability of an appeal from the Irish Supreme Court to the Judicial Committee of the Privy Council.

Section 2 of the Constitution of the Irish Free State (Saorstát Éireann) Act, 1922 appeared to confirm that the restrictions on Irish sovereignty found in the Treaty were beyond the amending power of the Oireachtas:

"The said Constitution shall be construed with reference to the Articles of Agreement for a Treaty between Great Britain and Ireland set forth in the Second Schedule hereto annexed (hereinafter referred to as 'the Scheduled Treaty') which are hereby given the force of law, and if the provisions of the said Constitution or of any amendment thereof or of any law made thereunder is in any respect repugnant to any of the provisions of the Scheduled Treaty, it shall, to the extent only of such repugnancy, be absolutely void and inoperative and the Parliament and the Executive Council of the Irish Free State (Saorstát Eireann) shall respectively pass such further legislation and do all such other things as may be necessary to implement the Scheduled Treaty."

Thus, the text of the 1922 Constitution - as accepted by the constituent assembly - made clear that the Oireachtas (Irish Parliament) could not amend the document's text in a manner that 
violated the Anglo-Irish Treaty of 1921. In light of this, many British politicians of the time considered the 'Irish Question' to have been constitutionally resolved: ${ }^{58}$

"... the British side certainly considered these to be real constraints which squarely confined the Irish Free State within the existing parameters of the prevailing Imperial/Commonwealth constitutional theory. There seems to have been no realisation on the part of the British side that the Irish Free State would successfully challenge and push back these boundaries over the next fifteen years. ${ }^{159}$

In 1922 Arthur Griffith had made an astute conclusion about the Treaty's long-term consequences, noting that it would 'practically recognise the Republic and the first allegiance would be to Ireland'. ${ }^{60}$ This indicates that regardless of the British view, even at the outset of the Free State era some Irish nationalists saw Ireland as 'practically' a Republic, even if not officially so. Nonetheless, as the 1920s went on the British establishment warmed to the Irish Free State and its Cosgrave-led government. King George even formally received the Dominion's great seal, and expressed privately - later recorded by Irish diplomats - a strong distain for De Valera's republicanism. ${ }^{61}$ The King was also highly critical of Mahatma Gandhi, relating a story of how he had lectured Mr. Gandhi and the rest of the Indian delegation about learning the lessons of Ireland's Dominion government:

"You have, doubtless, troubles in India. So has the Irish government in Ireland, and look what they have done... What I like about the Irish government is that it has a sense of reality. When they find themselves up against a difficulty they handle it and don't run away. ${ }^{62}$

Despite British confidence in the 1922 Constitution, and growing establishment respect for the Free State itself, neither would last much longer: by 1937, a mere 15 years after its difficult birth, the Irish Free State was no more.

\footnotetext{
${ }^{58}$ D. Harkness, Mr De Valera's dominion: Irish relations with Britain and the commonwealth, 1932-1938, 8 JOURNAL OF COMMONWEALTH POLITICAL STUDIES 206 (1970).

${ }^{59}$ G. Hogan, n 54, 1.

${ }^{60}$ Copy of secretary's notes of meeting of the cabinet and delegation held 3 December 1921 (No. 209 NAI DE 2/304/1) in DOCUMENTS ON IRISH FOREIGN POLICY VOLUME 1 1919-1922 345 (1998).

${ }^{61}$ 'Confidential report from John W. Dulaty to Joseph P. Walshe' (Dublin) (Secret and Confidential) 18 January 1932 No. 625 UCDA P35B/115 in DOCUMENTS ON IRISH FOREIGN POLICY VOLUME III 1926-1932, 897-898 (2002).

62 Ibid.
} 


\section{How the 1922 constitution came to be dismantled}

The legal process by which Ireland achieved its independence - by dismantling the 1922 Constitution and enacting the 1937 Constitution - is questionable, both from the perspective of Irish and of Imperial constitutional law.

\section{The Internal (Irish) Perspective}

As noted earlier, through the combined effect of Articles 47 and 50 of the 1922 Constitution it was intended that any amendment to the document's text would be subject to a popular referendum, requiring the assent of two-thirds of the vote recorded or a majority of the overall electorate - a sizeable burden. ${ }^{63}$ However, in order to allow constitutional 'fine-tuning' Article 50 additionally stated that from the date of its enactment there would be an eight year period within which amendments could be made by ordinary legislation passed by the Oireachtas. In 1928 and 1929, with the end of this eight-year limit looming, the Oireachtas controversially passed - via ordinary legislation - two amendments that removed Article 47 from the 1922 Constitution entirely and, crucially, extended the amending period in Article 50 by another eight years. ${ }^{64}$ In other words, the Irish parliament used its temporary, limited power under Article 50 to grant itself an extension to that very power. The effect of this was that 'the eightyear clause - originally intended simply to cover minor and technical amendments - ultimately proved to be the means whereby the entire 1922 Constitution was undone'. ${ }^{65}$

Although the extension of the amending power in this manner was controversial, it was not until 1934 that a challenge was brought to the Irish Supreme Court. This occurred in the seminal case of The State (Ryan) v Lennon. ${ }^{66}$ The case concerned a constitutional amendment passed by the Irish parliament in 1931, which led to the insertion of a new Article - 2A - into the 1922 Constitution. This amendment gave the Executive Council draconian powers: Article 2A claimed precedence over all subsequent articles - including the right to liberty - and provided

\footnotetext{
${ }^{63}$ Article 48 provided for an opportunity for citizens to initiate a constitutional amendment - a novel innovation alien to British constitutional law.

64 These were the 10th and 16th amendments of the 1922 Constitution.

65 G. Hogan, n 54, 6.

66 [1935] 1 I.R. 170.
} 
for a system of in-camera military justice at the Constitution (Special Powers) Tribunal, with no access or appeal to the courts, that potentially had retrospective reach, and also envisaged the imposition of the death penalty. In this case, the petitioners, Jeremiah Ryan, Hubert Johnston, John Harty and James Cantwell, held as suspects under the Offences Against the Person Act 1861 and due to be brought to trial at the Constitution (Special Powers) Tribunal, challenged their detention in a habeas corpus petition. They argued that the powers granted under Article 2A were unconstitutional because the 1931 amendment that inserted the Article into the 1922 document was made via ordinary legislation after the initial eight-year term in Article 50 had expired.

The detainees did not prevail. A 2-1 majority of the Irish Supreme Court held that there was no explicit language in Article 50, or elsewhere in the 1922 Constitution, that would indicate that the time-limited amending power ought not be used to extend the time period of that same amending power. Nevertheless, in a famously scathing minority dissent Kennedy C.J. referred to natural law to assert that the amendments could not be legal. He stated that the amendments - along with the draconian powers found in Article 2A - made a mockery of the rule of law, remarking that 'the Oireachtas has taken judicial power from the judiciary and handed it to the executive'. ${ }^{67}$

However, the majority ruling in the case did establish a crucial legal point - namely, that under Article 50 the legislature had the right to make any amendments it saw fit to the 1922 Constitution, with one explicit exception: because in 1922 the constituent assembly had accepted the terms of the 1922 Constitution and 1921 Treaty, the court's view was that no legislative amendments that breached the Treaty could be allowable under Article 50, as this would go against the declared will of the Irish constituent assembly.

Despite this ruling, amendments that clearly violated the will of the constituent assembly were passed by the legislature from 1933 onwards. ${ }^{68}$ The key figure in this process was De Valera, who had become President of the Executive Council following the Irish elections of 1932 and 1933. Once in power, De Valera used the Article 50 amending power to aggressively remove

\footnotetext{
67 [1935] 1 I.R. 170 at 202.

68 G. Hogan, n 54, 19, at fn 58, noting that it does not appear that anyone came forward to challenge these amendments in the Irish Courts at the time.
} 
the elements of the 1922 Constitution that tied the hands of Irish sovereignty e.g. the oath of allegiance, the recourse to the Privy Council, the office of Governor General, and later, the British monarch as the head of state. ${ }^{69}$

The use of the Article 50 legislative amending power - rather than the popular referendum process - was central to the deconstruction of the 1922 Constitution because the crucial amendments (such as the abolition of the oath and the office of Governor General) would likely not have had sufficient public support at the time to have been ratified by the required majority of the electorate. ${ }^{70}$ Despite this, De Valera's actions were viewed as acceptable - even justified - by many Irish politicians since for the most part they had been ill at ease with Westminster's claimed Imperial right to legislate the Irish Free State into being place in $1922 .{ }^{71}$

At the same time, the dissenting judgment of Kennedy C.J. in The State (Ryan) v Lennon, which warned of executive and legislative overreach, seems all the more powerful given the political climate elsewhere in 1930s Europe. ${ }^{72}$ Nonetheless, there was little chance that Ireland would become an illiberal dictatorship. Popular sovereignty - and specifically the pursuit of self-rule via democracy - was the central unifying principle common to both the supporters of Home Rule within the UK and to supporters of complete independence from Britain; in other words, democratic governance was the single principle that united nationalists of all stripes. ${ }^{73}$ Added to this is the fact that during this period of sporadic militant activity, Irish politicians used elections as a de-radicalisation tool - they helped give legitimacy to the state's young institutions, and in doing so took the wind out of the sails of the more extreme nationalists. ${ }^{74}$

\section{The External (Imperial) Perspective}

\footnotetext{
${ }^{69}$ Constitution (Removal of Oath) Act, 1933, Constitution (Amendment No. 22) Act, 1933, Constitution (Amendment No. 24) Act, 1936 and Constitution (Amendment) (No. 27) Act, 1936.

${ }^{70}$ G. Hogan, n 54, 5.

71 T. Mohr, The Statute of Westminster, 1931: An Irish Perspective, 31 LAW AND HISTORY REVIEW 749, 790-791 (2013).

72 G. Quinn, An Irish Tactic of Legality - The Legal Deconstruction of the Irish Free State - Presentation given at NUI Galway, 9 April 2016 - accessible at https://www.youtube.com/watch?v=9JWX3CpaDDk

73 There was a fascist movement in Ireland during the 1930s, commonly known as 'the Blueshirts' but it proved to be short-lived - M. Cronin, Catholicising Fascism, Fascistising Catholicism? The Blueshirts and the Jesuits in 1930s Ireland, 8 TOTALITARIAN MOVEMENTS AND POLITICAL RELIGIONS 401, 401-411 (2007).

${ }^{74}$ B. Kissane, n 36, 41-45.
} 
When considering the British Imperial legal perspective, a different - but not entirely unambiguous - picture emerges. Under Dicey's prevailing orthodox view of Parliamentary sovereignty it was uncertain whether the Imperial Parliament at Westminster could limit its own power to legislate on Ireland. ${ }^{75}$ On one hand, the Balfour Declaration of 1926, which led the Imperial Parliament to pass the Statute of Westminster in 1931, meant that by 1933, when the first crucial amendments were made, the Irish Free State possessed the legal right - under Imperial law - to remove the aspects of the 1922 Constitution imposed by the Anglo-Irish Treaty 1921. The Irish parliament's power to do this was confirmed in the 1935 decision of the JCPC in Moore v the Attorney General, which upheld the Free State's actions as legal under the Statute of Westminster. ${ }^{76}$ In other words, the 'Dominion equality' given to Ireland (and the other Dominions) by the Statute of Westminster empowered the Irish to remove themselves from the Dominion category entirely. ${ }^{77}$ Yet, it was still possible under Dicey's conception of Parliamentary sovereignty to argue that the Statute of Westminster 1931 was a power subject to what came before, and therefore not binding on later Westminster Parliaments. ${ }^{78}$ It was only when the competing theories of Sir Ivor Jennings and H.L.A. Hart, which argued that parliament could limit its own sovereignty, at least in procedural matters, became more accepted that this difficulty evaporated. ${ }^{79}$

\section{Reconciling Parliamentary Sovereignty and Constitutional Autochthony - the 1937 Constitution}

If there is a resolution to the above internal and external quandaries it is found in 1937. During the 1930s Éamon De Valera ha cleverly used the support of the leaders of the old Dominions, most prominently General Hertzog of South Africa, to gradually assert Ireland's political independence from Britain. ${ }^{80}$ But the remaining external and internal legal difficulties over the status of the 1922 document gave urgency to the argument that Ireland required a new

\footnotetext{
75 A.V. DICEY, n 16 and P. Oliver, n 16.

${ }^{76}$ Moore v. The Attorney-General for the Irish Free State [1935] A.C. 484. See also T. Mohr, Law without Loyalty, 37 IRISH JURIST 187 (2002) and D. KEOGH \& A. McCARTHY, THE MAKING OF THE IRISH CONSTITUTION 1937 (2007).

77 D.K. COFFEY, The Commonwealth and the Oath of Allegiance Crisis: A Study in Inter-War Commonwealth Relations, 44 THE JOURNAL OF IMPERIAL AND COMMONWEALTH HISTORY 492, 492-512 (2016).

78 A.V. DICEY, n 16 and P. Oliver, n 16.

79 I. JENNINGS, n 16 and H.L.A. Hart, Self-Referring Laws in H.L.A. HART (ed.), ESSAYS IN

JURISPRUDENCE AND PHILOSOPHY 170 (1983).

${ }^{80}$ R.M. DAWSON (ed.), THE DEVELOPMENT OF DOMINION STATUS 1900-1936 104-105 (2014).
} 
foundational text. In overseeing the drafting process of what would become the 1937 Constitution De Valera's aim was to retain the 1922 document's best features - the hybrid Westminster model featuring liberal rights-based review - and update it to take full account of independence. ${ }^{81}$ Furthermore, in order to head off any possible legal challenges to the state's legal legitimacy, Article 34.5 of the 1937 Constitution was enshrined to require every Irish judge to make a declaration to 'uphold the Constitution' - effectively preventing any member of the judiciary from questioning the legitimacy of the way in which the 1937 document had become the legal foundation of the state in the first place. ${ }^{82}$

In a neat coup de grace from De Valera, although the 1937 Constitution did include a timelimited amending power, similar to that found in Article 50 of the 1922 Constitution, under the terms of Article 51 of the new 1937 Constitution it was not legally possible to extend this period, because 'unlike Article 50 of the 1922 Constitution, it precluded the amendment of the amendment provisions themselves by means of ordinary legislation' ${ }^{83}$ Thus, it would have proven much more difficult to subvert the terms of the 1937 Constitution than it had been for the 1922 document. $^{84}$

On 1 July 1937, the 1937 Constitution was approved by a plebiscite, and was thus backed by the ultimate sovereignty of the people of Ireland. As Wheare remarks, this was a definitive break with Westminster as it was 'impossible to argue the new constitution obtained the force of law through the authority of the Dáil, which in turn had got its authority from the Statute of Westminster and the Irish Free State Constitution Act, 1922 - both Acts of Parliament of the United Kingdom'. ${ }^{85}$ The enactment of the 1937 Constitution thus represented a clear 'break in legal continuity' ${ }^{86}$ In effect, Ireland had acquired its own grundnorm. ${ }^{87}$

Therefore, although the dismantling of its predecessor came about due to a legislative programme that clearly subverted accepted principles of the rule of law, acceptance of the 1937 document by plebiscite shows that the new constitution had sufficient popular legitimacy for

\footnotetext{
${ }^{81}$ G. Hogan, n 54, 47.

82 G. Hogan, n 54, 20.

83 G. Hogan, n 54, 17.

84 M. Cronin, $\mathrm{n} 72$.

${ }^{85}$ K. WHEARE, n 16, 94.

86 P. Oliver, $\mathrm{n} 16$.

${ }^{87}$ H. KELSEN, GENERAL THEORY OF LAW AND STATE (1949).
} 
it to be an acceptable framework for Ireland's burgeoning republic, a status confirmed once Ireland left the Commonwealth in $1949 .{ }^{88}$ Indeed, the 1937 Constitution has proven to be a much more stable and enduring document than the 1922 document, and it has facilitated the development of a rich history of Irish constitutional jurisprudence. ${ }^{89}$ Nonetheless, the text is not without serious flaws.

The language of the preamble to the 1937 Constitution states explicitly that the mythical cause of the Irish Gaelic nation and the struggle of Jesus Christ and his followers are essentially one and the same. ${ }^{90}$ In this vein, the 1937 Constitution's recognition of the 'special position' of the Catholic Church coincided with, and confirmed, the Church's stewardship of the majority of the orphanages and hospitals of the state, making the state complicit in much of the child abuse that occurred within Church circles during the $20^{\text {th }}$ century. ${ }^{91}$ Ireland still struggles with this legacy today, despite the fact that the text recognising the 'special position' of the Catholic Church was removed after a constitutional referendum in 1972, and the fact that freedom of religion is protected by the current text. ${ }^{92}$ Clashes sometimes occur between the Christian character of the document and changes in popular will. Notably, divorce was not legal under the 1937 Constitution until a referendum was passed in $1995 .{ }^{93}$ Meanwhile, the definition of 'family' under Article 41 of the 1937 Constitution became a worldwide talking point in 2015 when the referendum on amendment of this Article was passed, which allowed recognition of same-sex marriage. ${ }^{94}$

\footnotetext{
88 S. Ó Tuama, Revisiting the Irish Constitution and De Valera's Grand Vision, 2 IRISH JOURNAL OF LEGAL STUDIES 54, 54-87 (2011).

89 O. Doyle, Legal Positivism Natural Law and the Constitution, 31 DUBLIN UNIVERSITY LAW JOURNAL 206 (2009).

90 Preamble, The Constitution of Ireland (Bunreacht na hEireann) 1937. The inability of Irish nationalism to incorporate 'other' non- Christian religious and ethnic backgrounds was a matter of contemporary discourse in the early 20th century - in James Joyce's 'Ulysses', the central character of Leopold Bloom, a converted Jew, has a confrontation with a committed nationalist - the 'Cyclops episode' - whereby Bloom's 'Irishness' is questioned. See J. JOYCE, ULYSSES 324-328 (1934). See also B. ANDERSON, IMAGINED COMMUNITIES 78 (2006). 91 Report by Commission of Investigation into Catholic Archdiocese of Dublin (The Murphy Report) (2009) http://www.justice.ie/en/JELR/Pages/PB09000504

92 Fifth Amendment of the Constitution Act, 1972.

93 Fifteenth Amendment of the Constitution Act, 1995.

94 The Thirty-fourth Amendment of the Constitution (Marriage Equality) Act 2015, amending Article 41 of the 1937 Constitution. See also Norris v A.G. [1984] IR 36 - the Victorian prohibition on homosexuality - via the The Offences against the Person Act 1861 and the Criminal Law Amendment Act 1885 - remained in force in Ireland until the state changed its laws after the ECHR judgment in Norris v Ireland [1991] 13 E.H.R.R. 186.
} 
In addition, the issue of partition remained unresolved in the 1937 text: the status of Northern Ireland - and its Unionist, and majority Protestant, community - was left ambiguous; and it was only with the passing of the Good Friday Agreement in 1998, approved by referendums on both sides of the border, that Ireland removed its territorial claim on Northern Ireland from the document's text. ${ }^{95}$

Ultimately, the Irish transition - from a constituent part of the United Kingdom of Great Britain and Ireland, to Dominion status, and thereafter to a republic - was, as Dicey had feared, a severe blow, both to his prevailing orthodox theory of Parliamentary sovereignty, and to the Empire itself. The Irish experience remained at the forefront of British minds during later negotiations over India, Pakistan and Ceylon. ${ }^{96}$

\section{The Influence of Ireland's experience on later Dominion constitutionalism}

The first constitutional legacy that links Ireland to the later new Dominions concerns India and the role of the Crown. During the 1921 Treaty negotiations, De Valera had put forward a plan for accommodating recognition of the British monarchy within an independent, republican Irish state, whereby the Crown would solely have 'external association' with Ireland. This idea, although dismissed by the British government in the 1920s, ended up becoming the model for republican India's relationship with the Crown, and later other republics in the Commonwealth such as Pakistan. ${ }^{97}$

The existence of tensions between the roles of constituent assemblies and the courts is a second common thread, most clearly visible in Ireland in the 1934 case of The State (Ryan) v Lennon, discussed above, and in Pakistan in the 1955 Tamizuddin case, in which the Pakistan Supreme Court accepted the Governor General of Pakistan's controversial decision to dissolve the constituent assembly, paving the way for military rule. ${ }^{98}$ Thus, while in Ireland the Supreme Court emphasised the importance of the role of the constituent assembly (though the relevant constitutional articles were later removed via legislation anyway), in Pakistan the Supreme

\footnotetext{
95 Nineteenth Amendment of the Constitution Act, 1998.

96 Reported in Parliament by The Secretary of State for India (Mr. Wedgwood Benn), and recorded in Hansard HC Deb 01 November 1929 vol. 231 cc473-5: accessible at http://hansard.millbanksystems.com/commons/1929/nov/01/india-viceroys-statement

97 W. David McIntyre, n 23, 391-413.

98 Federation of Pakistan v Maulvi Tamizuddin Khan PLD 1955 FC 240.
} 
Court sided with the executive over the assembly, and dealt a blow to Pakistan's democratic institutions. ${ }^{99}$

Partition is the third key point of comparison. Unresolved by the 1922 or 1937 Constitutions, partition in Ireland set the scene for a similar policy to be enacted in India/Pakistan. On this, contemporary discussions between Jawaharlal Nehru and Irish diplomats show that he considered the British to be attempting to do in India what Lloyd George had done in Ireland. ${ }^{100}$ By contrast, Mohammad Ali Jinnah, arguing in favour of partition in $1941,{ }^{101}$ drew an explicit parallel with the position of the (largely) Protestant Unionist community in Ireland and India's restive Muslims:

"The Irish Nationalist Leader, Redman [sic] ${ }^{102}$, met Carson, Ulster leader, and told him, 'Look here, can't we come to some settlement? Why do you want to separate from Ireland? Mind you, there is not one-millionth part of the differences between the people of Ulster and Ireland'. What was Carson's reply? 'I do not want to be ruled by you'. My reply to Mr Gandhi is, 'I do not want to be ruled by you'." 103

The entrenchment of sectarian partition in Ireland and Northern Ireland, India and Pakistan and later in Israel/Palestine - remains one of the costliest legacies of the end times of the British Empire, although a portion of the blame certainly rests with the key nationalist politicians of the era. ${ }^{104}$

More generally, although there were far fewer direct links between Ceylonese and Irish politicians, the Irish example was cited prominently during Ceylon's decolonization in 1948. ${ }^{105}$ Importantly, the British sought to avoid pushing Ceylon towards the full independence that

\footnotetext{
${ }^{99}$ M. Malagodi, Dominion status and the Origins of Authoritarian Constitutionalism in Pakistan, ICON submission (2017), on file with author.

100 'Confidential report from John W. Dulanty to Frederick H. Boland' (Dublin) (No. 1) 4 January 1947 No. 258 NAI DFA 417/22 in DOCUMENTS ON IRISH FOREIGN POLICY VOLUME VIII 1945-1948 303-304 (2013).

101 See generally F. DEVJI, MUSLIM ZION (2013).

102 Jinnah meant to refer to John Redmond MP, leader of the Irish Parliamentary Party during the early 20th century.

103 Quoted in T.G. FRASER, Ireland and India, in K. JEFFERY (ed.), "AN IRISH EMPIRE?" ASPECTS OF IRELAND AND THE BRITISH EMPIRE 91 (1996). See also D. MacMahon, The 1947 Partition of India: Irish Parallels, 18 HISTORY IRELAND 40 (2010).

104 See generally T.G. FRASER, PARTITION IN IRELAND, INDIA AND PALESTINE (1984).

105 H. Kumarasingham, n 3, 244.
} 
Ireland had achieved. As D.S. Senanayake negotiated with the British over Dominion status, Herwald Ramsbotham, 1st Viscount Soulbury, a former British Cabinet minister who would later be Ceylon's Governor General, stated that it 'would be a tragedy to repeat in Ceylon any of the colossal mistakes we have made in Ireland. ${ }^{106}$ Soulbury went on to emphasise that if Senanayake was unable to secure Dominion status for Ceylon swiftly, he was likely to lose control of the legislature, and potentially, the entire nationalist movement, something that would likely transform Ceylon from a being 'a loyal friend of Britain and the Crown to being more akin to Ireland'. ${ }^{107}$

Finally, the novel elements of Irish constitutionalism - which expanded the Westminster model by providing for rights-based review - were directly influential on later transitional and postimperial constitution-building, especially in India. Most explicitly, the 1937 Irish Constitution's 'Directive Principles of State Policy' were reflected in the 1950 Constitution of India (both the Irish and Indian versions were enacted for the same purpose: as non-justiciable principles to provide guidance to the legislature for making social policy). ${ }^{108}$ The textual influence is very strong - Article 45 of the 1937 Irish Constitution lists the Directive Principles of Social Policy and states at Article 45.1:

"The state shall strive to promote the welfare of the whole people by securing and protecting as effectively as it may a social order in which justice and charity shall inform all institutions of national life."

The same text, without the words 'and charity' was reproduced in Article 38 of the 1950 Indian Constitution. ${ }^{109}$

\footnotetext{
106 Soulbury to Hall, 5 Oct. 1945, CO54/986/6/3, 174 in K.M. DE SILVA (ed.), SRI LANKA, PART II TOWARDS INDEPENDENCE 1945-1948, BRITISH DOCUMENTS ON THE END OF EMPIRE (SERIES B, VOLUME 2) 110-113 (1997), as referred to by H. Kumarasingham, n 3, 244.

107 Ibid.

108 J. Usman, Non-Justiciable Directive Principles: A Constitutional Design Defect, 15 MISC. ST. J. INT'L L. 643 (2007) and B. De Villiers, Directive Principles of State Policy and Fundamental Rights: The Indian Experience, 8 S. AFR. J. ON HUM. RTS. 29 (1992).

109 The Constitution of India (As on $9^{\mathrm{TH}}$ November 2015) - http://lawmin.nic.in/olwing/coi/coi-english/coi4March2016.pdf
} 


\section{Conclusion}

As a Dominion from 1922-1937 Ireland represents a bridge between the old Dominions of Canada, Australia, New Zealand and South Africa, and the later new Dominions of India, Pakistan and Ceylon. Ireland possessed strong links with the old Dominions - especially Canada and South Africa - while also fostering links with anti-imperial movements elsewhere in the Empire.

From a constitutional perspective, Ireland was the first of the Dominions to push against the legal limits of Dominion status, and to grapple with the implications of the prevailing Diceyan concept of Westminster Parliamentary Sovereignty. As show in this article, when the Irish legislature amended the 1922 Constitution to remove the badges of inferiority imposed by Dominion status, legal complications arose both from the internal (Irish) and external (Imperial) constitutional perspectives. Eventually, the only way to escape these difficulties was to bring forward a new foundational document - the 1937 Constitution - accepted by plebiscite in $1937 .{ }^{110}$ The enactment of the 1937 Constitution created a definitive break in legal continuity with the Westminster Parliament and established Ireland's constitutional autochthony in line with the theories of Wheare, Robinson, Marshall and Oliver, and defying the more orthodox view of Dicey. ${ }^{111}$ Put simply, the legal problems arising from the British imposed Dominion constitution and Parliamentary sovereignty were corrected by the new constitutive act performed by the Irish people in 1937. ${ }^{112}$

The Irish experience remained at the forefront of British minds during later negotiations over India, Pakistan and Ceylon. ${ }^{113}$ Indeed, Ireland became an important and influential legal and political reference point for later British/Dominion constitutional arrangements over a wide range of issues, including external association with the Crown (India); conflicts between the roles of the courts and constituent assembles (Pakistan); the enshrinement of partition

\footnotetext{
${ }^{110} \mathrm{~K}$. WHEARE, n 16.

111 K. Robinson, n 16, G. MARSHALL, n 16 and P, Oliver, n 16.

112 T. Poole, n 24, 9. See also H. Lindahl, The Paradox of Constituent Power: The Ambiguous Self-Constitution of the European Union, 20 RATIO JURIS 485, 498-499 (2007). Though external (Westminster) recognition occurred with the Eire (Confirmation of Agreements) Act, 1938, this came after the fact - a new internal legitimacy had already been asserted in 1937.

113 Reported in Parliament by The Secretary of State for India (Mr. Wedgwood Benn), and recorded in Hansard HC Deb 01 November 1929 vol. 231 cc473-5: accessible at http://hansard.millbanksystems.com/commons/1929/nov/01/india-viceroys-statement
} 
(India/Pakistan); and the accommodation of restive territories within the Dominion model (Ceylon). Furthermore, the Irish experience of adapting - perhaps, subverting - the Westminster model to local needs proved to be influential - as seen explicitly with the Indian adoption of the 1937 Irish Constitution's 'Directive Principles' in the 1950 Indian Constitution. ${ }^{114}$

Moreover, historical documents show that the Irish government cared deeply about maintaining its status as a bridge between the old settler colonies and the new Dominions and independent states that were emerging from the Empire. ${ }^{115}$ As the racial tensions in South Africa began to dominate politics in the country in the 1950s - leading eventually to apartheid - the Irish government found itself in a delicate position: it did not want to lose its position as a leading light of anti-imperialism, but also did not want to anger the Afrikaners who had been very supportive of Ireland during the Dominion period. ${ }^{116}$ Whether Ireland succeeded in maintaining an appropriate balance is up for debate, but one of the benefits of independence from Britain was the ability to plough its own furrow and develop a unique foreign policy.

To conclude, the Irish transition - from a constituent part of the United Kingdom of Great Britain and Ireland, to Dominion status, and thereafter to a republic - was, as Dicey had feared, a severe blow, both to his prevailing orthodox theory of Parliamentary sovereignty, and to the Empire itself. Further, in terms of building on the Westminster model it is notable that Ireland was ahead of British Constitutionalism in two major respects. Perhaps the most significant changes to the UK constitutional system over the past few decades have been: (i) the growing importance of referendums (over issues including Scottish independence and 'Brexit'); and (ii) the expansion of judicial review via a liberal human rights framework. ${ }^{117}$ Ireland already possessed these innovations from the 1922 Constitution onward, and they were further entrenched in the 1937 Constitution. In other words, the situation is rather more serious than Dicey ever imagined: not only did the Irish Dominion signal the end of the Empire, over the past decades the traditional British constitution has come to resemble more closely one of its post-imperial descendants.

\footnotetext{
114 W. David McIntyre, n 23, 365.

115 'Letter from Valentin Iremonger to Willian B. Butler' (Dublin) (318/69) 14 September 1950 in DOCUMENTS ON IRISH FOREIGN POLICY VOLUME IX 1948-1951 595 (2014).

116 Ibid.

117 T. Poole, n 23, 21.
} 
